\title{
Observations on the act of eating in cattle
}

\author{
By C. C. BALCH \\ National Institute for Research in Dairying, Shinfield, Reading \\ (Received 26 March 1958)
}

In any consideration of normal reticulo-ruminal function the act of eating is likely to play a highly important part. When food is eaten, or shortly afterwards, critical events occur in the reticulo-rumen such as the maximum daily inflow of saliva and water inducing the minimum concentration of micro-organisms, the sudden change from the least to the greatest weight and volume of the contents and the greatest daily change in the composition of the contents. The primary object of this paper is to present relevant information on these matters obtained, sometimes incidentally, in a number of experiments. Observations have been grouped under four headings: saliva production, the rate of movement of the jaw, the rate of contraction of the reticulum and the change in the amount of digesta present in the reticulo-rumen. As a secondary object the findings have been examined to see whether they throw light on the mechanism determining the point at which a cow stops eating food which has been offered ad lib.

\section{EXPERIMENTAL AND RESULTS}

The experiments were conducted on Shorthorn cows and Holstein steers in which large rumen fistulas had been established; the fistulas were closed by means of rubber cannulas and bungs similar to those described earlier (Balch \& Johnson, 1948).

\section{Saliva secreted during eating}

The saliva secreted during eating was measured by catching the food boluses as they arrived in the rumen. For this purpose a rubber bag was constructed from a large punchball bladder, a double metal ring (about $10 \mathrm{~cm}$ in diameter) being inserted to give a rigid opening which could be held over the cardia (Pl. I).

Weight of saliva secreted with different foods. The mean dry-matter contents of boluses of hay, concentrates in meal form and as cubes, flaked maize, fodder beet and grass, which represent some of the main classes of cattle foods, are shown in Table $\mathrm{r}$. It was found that whereas the boluses of hay averaged only $12-16 \%$ dry matter in six animals, those of concentrates, in the usual coarsely ground form, in five animals averaged $35^{-}$ $40 \%$, which meant that, whereas to every Io $\mathrm{lb}$. hay the animal added $43-57 \mathrm{lb}$. saliva, only $12-15 \mathrm{lb}$. were added to every Io $\mathrm{lb}$. concentrates in meal form. Rather less saliva was added to concentrates given as cubes, although by the time the cubes reached the reticulo-rumen they had been almost completely ruptured. When cubes were finely ground and the resulting powder was given on isolated occasions, the animals ate it 
slowly, and with suspicion, and considerably more saliva was added to it than to concentrates in the more coarsely ground form.

The dry-matter contents of boluses of fodder beet and grass were lower than those of hay, and it was calculated that for every ro $\mathrm{lb}$. dry matter consumed as fodder beet the two animals tested added on an average 27 and $33 \mathrm{lb}$. saliva whereas for every $10 \mathrm{lb}$. dry matter consumed as grass three cows added $45,6 \mathrm{I}$ and $56 \mathrm{lb}$. saliva, respectively.

Table I. Dry-matter content of boluses and weight of saliva produced in cattle during eating (mean value and standard deviation of values for single meals)

\begin{tabular}{|c|c|c|c|c|c|}
\hline \multirow[b]{2}{*}{ Food } & \multirow[b]{2}{*}{ Animal } & \multirow{2}{*}{$\begin{array}{l}\text { No. of meals } \\
\text { at which the } \\
\text { food boluses } \\
\text { were sampled }\end{array}$} & \multirow{2}{*}{$\begin{array}{c}\text { Dry-matter } \\
\text { content of } \\
\text { food boluses } \\
(\%)\end{array}$} & \multicolumn{2}{|c|}{ Saliva added } \\
\hline & & & & lb./1olb. food & lb./ Io lb. dry matter \\
\hline Hay & $\begin{array}{l}\text { Cow W } \\
\text { Cow H } \\
\text { Cow D } \\
\text { Cow L } \\
\text { Steer A } \\
\text { Steer D }\end{array}$ & $\begin{array}{r}8 \\
5 \\
10 \\
4 \\
6 \\
6\end{array}$ & $\begin{array}{l}14.2 \pm 0.1 \\
16.4 \pm 0.1 \\
15.4 \pm 2.5 \\
12.5 \pm 0.4 \\
13.7 \pm 0.5 \\
14.9 \pm 0.4\end{array}$ & $\begin{array}{l}50 \cdot 2 \pm 4 \cdot 2 \\
43 \cdot 0 \pm 2 \cdot 1 \\
46 \cdot 8 \pm 9 \cdot 0 \\
56 \cdot 9 \pm 2 \cdot 3 \\
54 \cdot 7 \pm 2 \cdot 5 \\
49 \cdot 5 \pm 1 \cdot 7\end{array}$ & $\begin{array}{l}58 \cdot 9 \pm 4 \cdot 4 \\
49 \cdot 6 \pm 2 \cdot 4 \\
55 \cdot 1 \pm 11 \cdot 3 \\
67 \cdot 9 \pm 2 \cdot 8 \\
61 \cdot 8 \pm 2 \cdot 7 \\
55 \cdot 9 \pm 1 \cdot 8\end{array}$ \\
\hline $\begin{array}{l}\text { Concentrates: } \\
\text { In meal form }\end{array}$ & $\begin{array}{l}\text { Cow H } \\
\text { Cow D } \\
\text { Cow L } \\
\text { Steer A } \\
\text { Steer D } \\
\text { Cow D } \\
\text { Cow K }\end{array}$ & $\begin{array}{r}6 \\
10 \\
4 \\
6 \\
6 \\
4 \\
4\end{array}$ & $\begin{array}{l}35 \cdot 4 \pm 1 \cdot 5 \\
37 \cdot 7 \pm 2 \cdot 2 \\
37 \cdot 0 \pm 1 \cdot 0 \\
39 \cdot 6 \pm 2 \cdot 5 \\
40 \cdot 1 \pm 2 \cdot 5 \\
45 \cdot 9 \pm 1 \cdot 9 \\
40 \cdot 6 \pm 3 \cdot 0\end{array}$ & $\begin{array}{r}\text { I } 4 \cdot 8 \pm 1 \cdot 0 \\
\text { I } 3 \cdot 2 \pm 2 \cdot 5 \\
\text { I } 3 \cdot 1 \pm 0.6 \\
\text { I } 2 \cdot 1 \pm 1 \cdot 6 \\
\text { II.8 } 11 \cdot 3 \\
8 \cdot 9 \pm 0.4 \\
\text { II. } 3 \pm 0.8\end{array}$ & $\begin{array}{l}16.8 \pm 1.3 \\
15.2 \pm 3.0 \\
15.4 \pm 0.8 \\
13.9 \pm 1.8 \\
13.5 \pm 1.6 \\
10.2 \pm 0.4 \\
13.0 \pm 1.0\end{array}$ \\
\hline Flaked maize & $\begin{array}{l}\text { Cow D } \\
\text { Cow K }\end{array}$ & $\begin{array}{l}2 \\
2\end{array}$ & $\begin{array}{l}38 \cdot 5 \\
33 \cdot 5\end{array}$ & $\begin{array}{l}I 2 \cdot 1 \\
15 \cdot 4\end{array}$ & $\begin{array}{l}14 \cdot 2 \\
18 \cdot 1\end{array}$ \\
\hline Fodder beet & $\begin{array}{l}\text { Cow D } \\
\text { Cow L }\end{array}$ & $\begin{array}{l}4 \\
4\end{array}$ & $\begin{array}{l}1 \times \cdot 4 \pm \mathrm{r} \cdot \mathrm{I} \\
10.6 \pm 0.6\end{array}$ & $\begin{array}{l}4.5 \pm 1 \cdot 4 \\
5.4 \pm 0.7\end{array}$ & $\begin{array}{l}27 \cdot 3 \pm 6 \cdot 4 \\
33 \cdot 2 \pm 4 \cdot 8\end{array}$ \\
\hline Grass & $\begin{array}{l}\text { Cow W } \\
\text { Cow H } \\
\text { Cow I }\end{array}$ & $\begin{array}{l}7 \\
1 \\
1\end{array}$ & $\begin{array}{l}9 \cdot 4 \pm I \cdot 0 \\
8 \cdot 2 \\
9 \cdot 0\end{array}$ & $\begin{array}{l}7 \cdot 5 \pm 2 \cdot 7 \\
10 \cdot 1 \\
10 \cdot 2\end{array}$ & $\begin{array}{l}45 \cdot 4 \pm 13 \cdot 7 \\
61 \cdot 2 \\
56 \cdot 5\end{array}$ \\
\hline
\end{tabular}

Thus, the weight of saliva added per lb. food consumed varied very markedly, being greatest with hay, least with succulent foods and surprisingly low with concentrates.

Rate of secretion of saliva during eating. The various classes of cattle foods are eaten at greatly varying rates, hay being eaten slowly and concentrates more rapidly. Duplicated tests were done with two cows to find whether the rate of secretion of saliva was influenced by these foods. The results are shown in Table 2 , and the values for saliva added per $10 \mathrm{lb}$. food were similar to the mean values given in Table I for hay, concentrates and fodder beet. It is clear from Table 2 that, although saliva was secreted at the rate of 5-6 lb./ Io min when the cows were eating hay, the rate with concentrates increased to $7-12 \mathrm{lb}$./10 min, whereas with fodder beet it was only $3-5 \mathrm{lb}$./10 min.

The rate of saliva secretion when concentrates were eaten was, therefore, somewhat faster than with hay which in turn was faster than with fodder beet. The extreme dryness of the food bolus formed from concentrates was the result of rapid eating and occurred in spite of the approximately two-fold increase in the rate of secretion of saliva. Further work is being undertaken on this subject. 
Rate of secretion of saliva at different times during meals. The ingestion of a large meal of hay may take $2 \mathrm{~h}$ or more. In an attempt to determine whether the rate of flow of saliva changed during the course of a meal, food boluses were collected at intervals throughout medium-sized meals of hay. Values for three cows are shown in Fig. I. There was no marked tendency for the dry-matter content of the boluses to change as the meal progressed, although a trend towards a lower content is suggested by the results (see also Fig. 3).

Table 2. Rate of secretion of saliva in cows eating hay, concentrates and fodder beet

\begin{tabular}{|c|c|c|c|}
\hline \multicolumn{4}{|c|}{ (Two observations/cow) } \\
\hline \multirow[b]{2}{*}{ Food } & \multirow[b]{2}{*}{ Cow } & \multicolumn{2}{|c|}{ Saliva added } \\
\hline & & lb./ Iolb, food & lb. $/ 10 \mathrm{~min}$ \\
\hline \multirow[t]{4}{*}{ Hay } & $\mathrm{L}$ & $56 \cdot 5$ & 5.42 \\
\hline & & $53 \cdot 9$ & $5 \cdot 39$ \\
\hline & $\mathrm{D}$ & $48 \cdot 6$ & $5 \cdot 15$ \\
\hline & & $57 \cdot 0$ & 6.33 \\
\hline \multirow[t]{4}{*}{ Concentrates } & $\mathrm{L}$ & $12 \cdot 8$ & $7 \cdot 30$ \\
\hline & & $13 \cdot 9$ & $8 \cdot 90$ \\
\hline & D & $14 \cdot 4$ & $9 \cdot 16$ \\
\hline & & $18 \cdot 3$ & $12 \cdot 2 \mathrm{I}$ \\
\hline \multirow[t]{3}{*}{ Fodder beet } & $\mathrm{L}$ & $6 \cdot 2$ & $3 \cdot 66$ \\
\hline & & $5 \% 7$ & $3 \cdot 28$ \\
\hline & $\mathrm{D}$ & $\begin{array}{l}4 \cdot 9 \\
2 \cdot 6\end{array}$ & $\begin{array}{l}5 \cdot 35 \\
2 \cdot 65\end{array}$ \\
\hline
\end{tabular}

\section{Rate of movement of the jaw during eating}

The movements of the jaw were recorded by means of toy balloons $(c .7 \mathrm{~cm}$ in length) placed under one of the straps of a leather head-stall. The balloons were held on special balloon holders to prevent kinking and connected by pressure tubing to tambours operating pens leaving a continuous ink record on white paper (Balch, Kelly \& Heim, 1950).

The movements of the jaws of three cows were each recorded twice during the ingestion of large meals of hay and the mean rate of contraction was counted at intervals of 5 min throughout the meal. The results (Table 3 ) show clearly that the cows ate steadily at a mean rate of $75-8 \mathrm{r}$ jaw movements per min. There was some fluctuation in the rate of movement, but no consistent tendency. The records did, however, show that towards the end of the meal eating usually became spasmodic, periods in which the animal ate at the usual rate being interspersed with periods of idleness, drinking or rubbing. The definite end of eating was usually marked by the animal lying down or beginning to ruminate.

The movements of the jaw were somewhat different when concentrates and roughages were eaten and resulted in a slightly different pattern on the recorder charts. With practice it was possible to distinguish between the records when these foodstuffs were eaten. The records obtained from a cow eating concentrates had a wavy appearance and suggested that the mouth was not opened wide; the records taken from cows eating hay showed a more regular pattern with a level base-line. 
During drinking the mouth opened less widely than during eating and moved at a slower rate.

In cows $\mathrm{D}, \mathrm{H}$ and $\mathrm{W}$ it was found that typical rates of jaw movement when hay was eaten were $76,7^{2}$ and $82 / \mathrm{min}$, respectively; during drinking the rates were 38,25 and 2I. In cows $\mathrm{D}$ and $\mathrm{H}$ the rates when concentrates were eaten were 88 and $90 / \mathrm{min}$, respectively. Fuller (1928) reported a mean rate of jaw movement of $94 / \mathrm{min}$ with concentrates, 78 with hay and 55 during rumination.

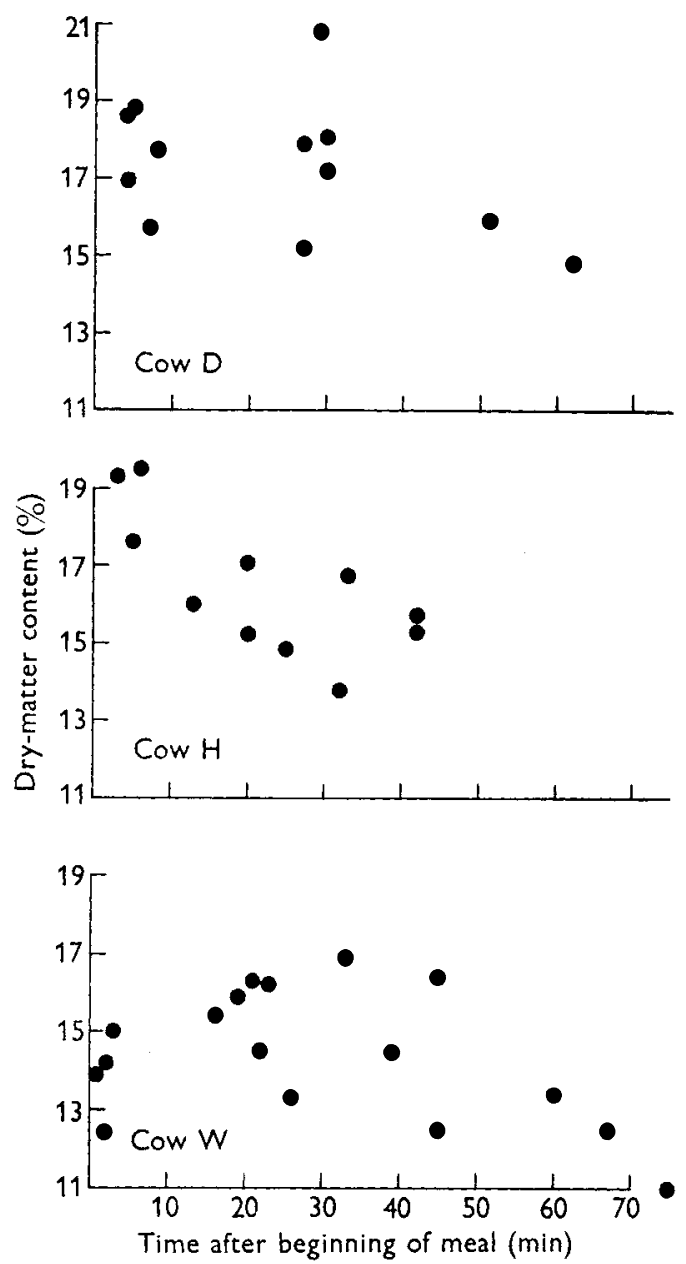

Fig. I. Dry-matter content of boluses of hay at intervals after the beginning of eating.

It is of interest that in a meal lasting roo min, during which a cow might eat 1o $\mathrm{lb}$. hay, it would probably open and close its mouth about 800 times.

During rumination the jaw movement in cows $\mathrm{D}, \mathrm{H}$ and $\mathrm{W}$ was somewhat slower and more regular. A rate of about 58 jaw movements/min was recorded although the periods of chewing were frequently rather less than I min in duration. 
Table 3. Rate of movement of the jaw during periods in which the cows were eating hay

\begin{tabular}{|c|c|c|c|c|c|c|c|}
\hline \multirow{3}{*}{$\begin{array}{l}\text { Time after } \\
\text { beginning of } \\
\text { meal (min) }\end{array}$} & \multicolumn{7}{|c|}{ Jaw movements (rate/min) } \\
\hline & \multicolumn{2}{|c|}{ Cow D } & \multicolumn{2}{|c|}{ Cow $\mathrm{H}$} & \multicolumn{2}{|c|}{ Cow W } & \multirow[b]{2}{*}{ Mean } \\
\hline & Day 1 & Day 2 & Day I & Day 2 & Day I & Day 2 & \\
\hline 5 & 67 & 80 & 66 & 78 & 78 & 84 & 76 \\
\hline IO & 75 & 80 & 64 & 69 & 80 & 82 & 75 \\
\hline I 5 & 77 & 74 & 68 & 72 & 84 & 88 & 77 \\
\hline 20 & 73 & 82 & 67 & 69 & 78 & 83 & 75 \\
\hline 25 & 82 & 73 & 70 & 71 & 86 & 84 & 78 \\
\hline 30 & 74 & 80 & 70 & 70 & 79 & 77 & 75 \\
\hline 35 & 73 & 80 & 72 & 67 & 76 & 83 & 75 \\
\hline 40 & 87 & 75 & 73 & 75 & 84 & 92 & 81 \\
\hline 45 & 73 & 86 & 75 & - & 88 & 77 & 80 \\
\hline 50 & 75 & 88 & $7 \circ$ & $\cdots$ & 84 & 83 & 80 \\
\hline 55 & 71 & 83 & 64 & 74 & 78 & 92 & 77 \\
\hline 60 & 71 & 79 & 65 & 71 & 82 & 83 & 75 \\
\hline 65 & 68 & 84 & 67 & 78 & 83 & 93 & 79 \\
\hline 70 & 80 & 89 & 69 & 86 & 82 & - & $8 \mathrm{I}$ \\
\hline 75 & 73 & 79 & 69 & 82 & 78 & - & 76 \\
\hline 80 & 73 & 82 & Ends & 67 & 73 & - & - \\
\hline 85 & 70 & 77 & - & 88 & 80 & 75 & 78 \\
\hline 90 & $(62)$ & 71 & - & 80 & 77 & 86 & 75 \\
\hline 95 & 71 & 82 & $\ldots$ & 74 & 76 & $8_{3}$ & 77 \\
\hline 100 & 59 & 82 & - & 74 & $\left(6_{5}\right)$ & Ends & - \\
\hline 105 & (7I) & $7 x$ & - & Ends & (58) & - & - \\
\hline IIO & $6_{3}$ & Ends & - & -- & $(59)$ & - & - \\
\hline II 5 & 68 & - & - & - & Ends & - & - \\
\hline 120 & $(6 \mathrm{I})$ & - & - & 一 & - & - & - \\
\hline 125 & Ends & - & - & - & - & - & - \\
\hline
\end{tabular}

\section{Rate of contraction of the reticulum during eating}

Reticulum movements were recorded by the apparatus used for jaw movements, the balloons being maintained in the reticulum by means of a weight.

The acceleration of the reticulum movements and an increase in the amplitude of the recorded contractions were so marked during eating that they enabled the periods of eating to be identified from kymographic tracings showing only reticulum contractions (Balch, 1952). Previous work had not, however, demonstrated the extent to which this increased rate was maintained throughout the meal. Records made on three or four occasions when two cows were eating large meals were therefore examined and mean values are shown in Fig. 2. Apart from marked and consistent differences between cows, the records showed clearly that as a meal of hay progressed the rate of contraction of the reticulum declined little if at all. The initial rate of contraction was higher when concentrates were present in the food than when it consisted solely of hay, and throughout the feeding period there appeared to be a slow decline in the rate of contraction. There was, however, no tendency for the rate of contraction to decline more rapidly immediately before the end of eating with food freely available and there was no evidence to suggest that fatigue of the reticulo-ruminal musculature was a limiting factor in appetite. When the food consisted of hay, concentrates and fodder beet, the rate of contraction declined steadily throughout the meal. 
Change in the contents of the reticulo-rumen

Weights of digesta in the reticulo-rumen were determined by completely removing through the fistulas the entire contents into large straight-sided buckets. The contents were weighed, sampled and immediately returned to the rumen. In later experiments

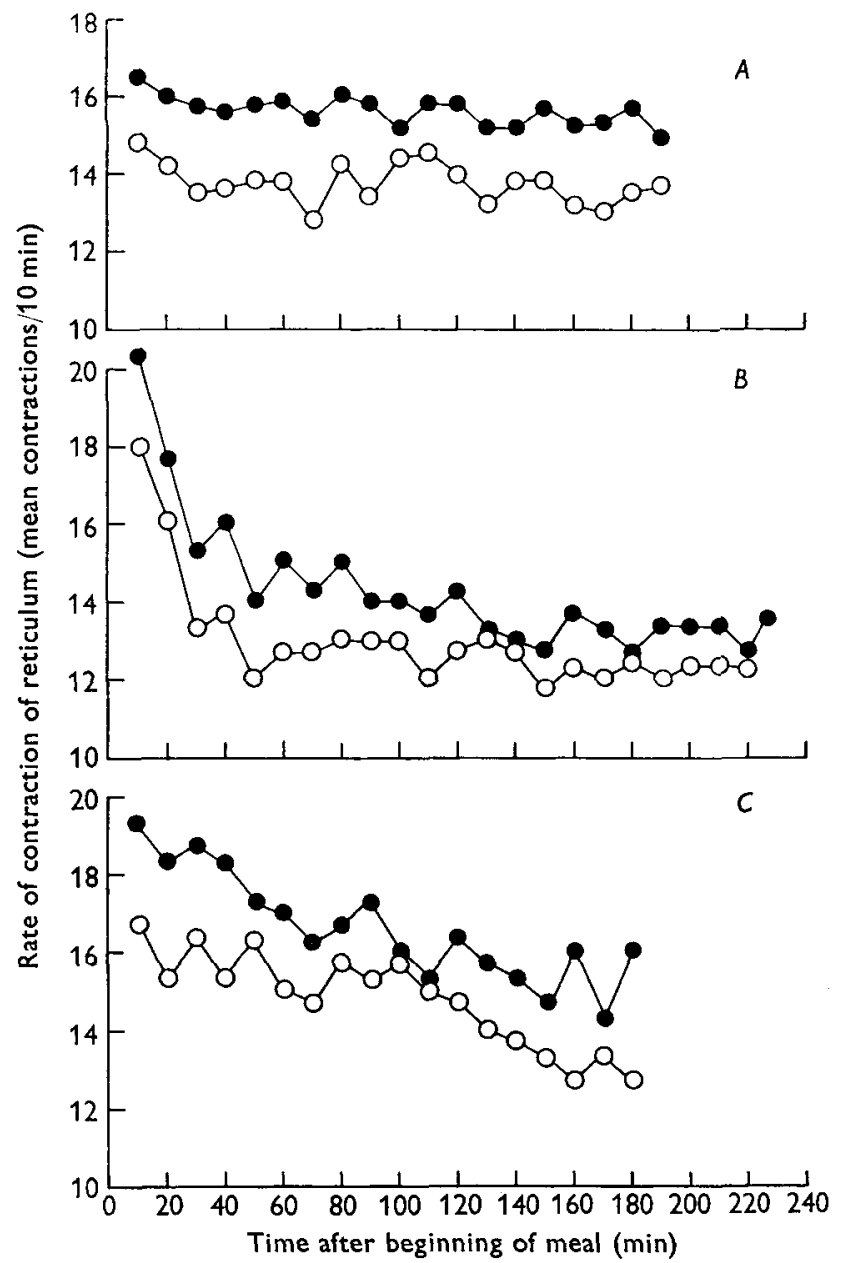

Fig. 2. Rate of contraction of the reticulum in cows $\mathrm{L}$, $\bullet$, and $\mathrm{D}, \mathrm{O}$, during meals of $(A)$ I $8 \mathrm{lb}$. hay, $(B)$ Io $\mathrm{lb}$. concentrates and $\mathrm{I} 6 \mathrm{lb}$. hay, and $(C) 6 \mathrm{lb}$. concentrates, $50 \mathrm{lb}$. fodder beet and $8 \mathrm{lb}$ hay. Values are means for three or four meals. The concentrates were consumed in the first $20 \mathrm{~min}$ of eating and were followed by hay or fodder beet. In the third period the hay was given about $2 \mathrm{~h}$ after the fodder beet.

the volume of digesta in the pails was determined before sampling. The dry-matter contents of foods, food boluses and digesta were determined by drying to constant weight at $90^{\circ}$.

During eating. The immediate effects of eating on the weights of digesta in the reticulo-rumen were measured by removing, weighing and returning the digesta from 


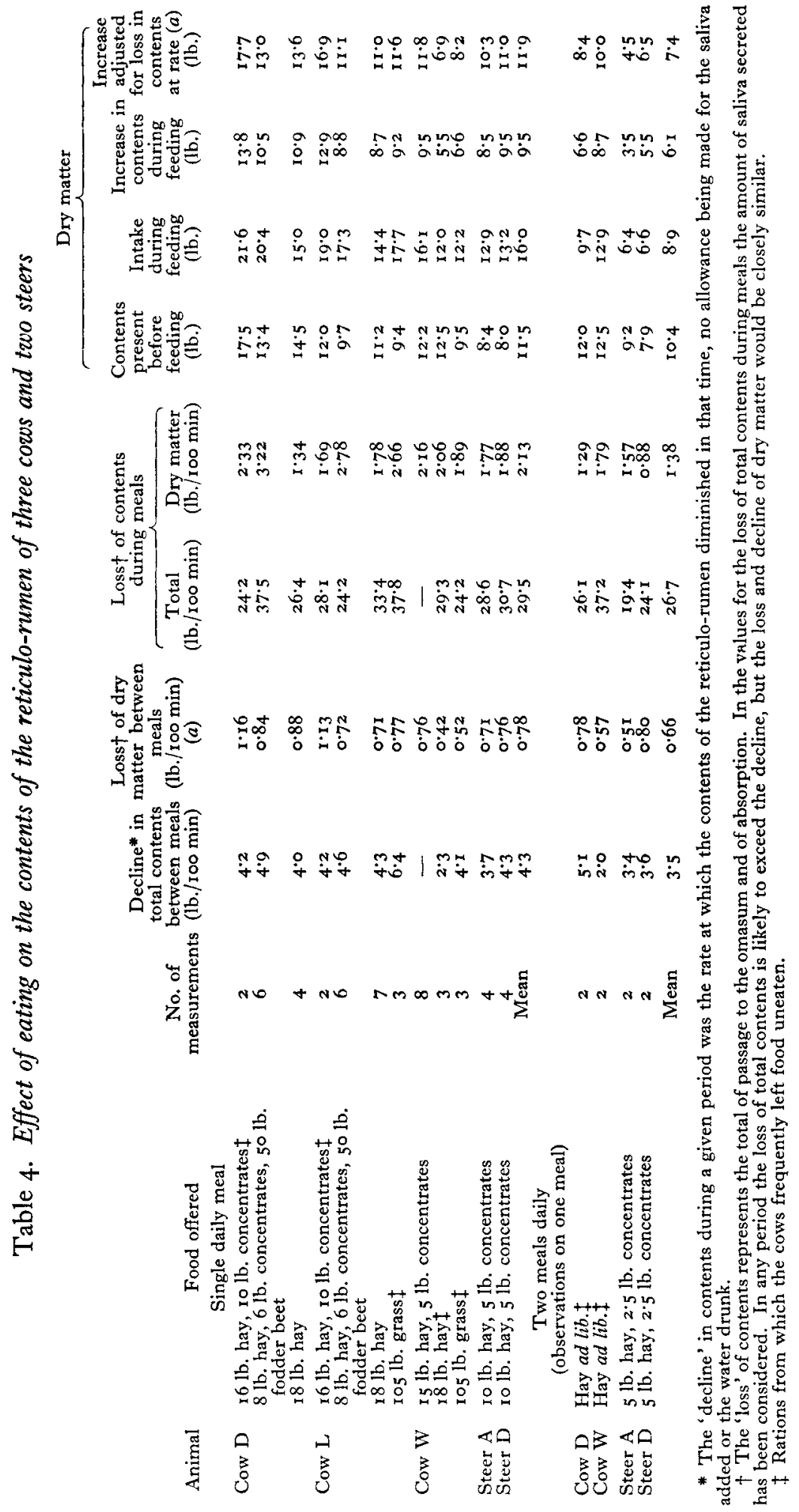


three cows and two steers before and after feeding. The values (Table 4) were obtained mainly while the animals were given all their daily allowance of food in one large meal occupying 300-360 min with the cows and 200-250 min with the steers.

The rate of loss (by passage and absorption) between meals was calculated by subtracting the total dry matter before feeding from the total dry matter at the end of feeding and expressing the difference as the mean loss/100 min. The values found were 0.8 and $0.7 \mathrm{lb}$. for cattle fed once and twice daily, respectively. The rate of loss during feeding, however, proved to be substantially greater, and the actual measured increase in total contents and dry matter was less than the quantities of food, water and saliva actually ingested. From Table 4 it can be seen that on an average the actual dry matter ingested was $\mathrm{I} 6 \cdot \mathrm{l} \mathrm{lb}$. for animals fed once a day although the observed increase was only $9.5 \mathrm{lb}$. The difference, $6.5 \mathrm{lb}$., must have been lost by passage to the omasum and

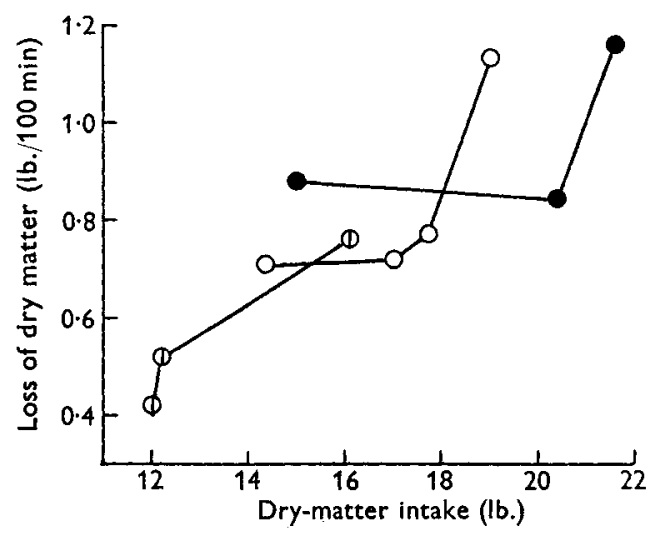

Fig. 3. Relationship between the rate of loss of dry matter from the reticulo-rumen in the period between single daily meals and the dry-matter intake during the meals. Values are shown for cows $D, \bullet ; L, O$; and $W, \oplus$.

by absorption. This value expressed as $\mathrm{lb}$. dry matter per min gives the rate of loss, $2 \cdot \mathrm{I}_{3} \mathrm{lb}$. for cattle fed once a day and $\mathrm{r} \cdot 38 \mathrm{lb}$. for cattle fed twice a day. Since the intake of food was spread more or less evenly over the period of eating, the rate of loss at certain times during the meal may have been considerably greater than the average. Because of the lack of a measure of the amount of saliva added in periods when the animals were not eating, it was not possible to calculate the rate of loss of total contents in such periods, and the changes observed in the total contents are therefore referred to as declines rather than as losses. The mean rate of decline is given in Table 4 $(4.3 \mathrm{lb}$./ $100 \mathrm{~min}$ with one and $3.5 \mathrm{lb}$. with two meals daily), and it seems very unlikely that sufficient saliva can have been produced or water drunk to make the rate of loss approach the high values $(29.5 \mathrm{lb}$./ $100 \mathrm{~min}$ with one and $26.7 \mathrm{lb}$. with two meals daily) found during the periods of eating.

With the various diets studied it appeared that the rate of loss of dry matter from the rumen between meals was regulated by the intake of dry matter (Fig. 3). During meals the relationship was less regular, and it is possible that the volume of the food was of importance; the bulkiness of fodder beet may explain the high rate of loss observed 
when cows $D$ and $L$ received it; it is likely, however, that the amount of digesta present initially was also of importance.

After eating. Mean values for the rate at which the contents of the reticulo-rumen continued to decline after eating had ceased are also given in Table 4. As stated above, the values for dry matter represent the actual loss by passage and absorption, but the loss of total contents will have been higher than the decline shown, owing to the secretion of saliva. The values may be of use if combined with those for total contents measured directly or with mean values (cf. Balch \& Line, 1957) in estimating the

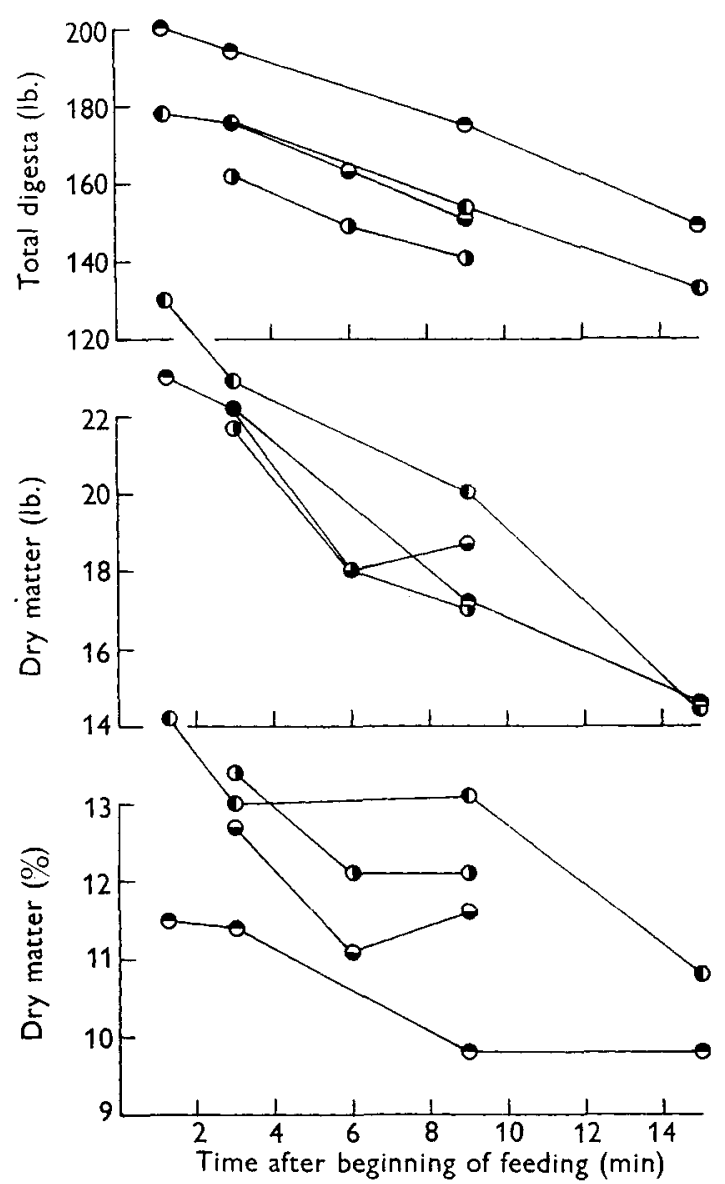

Fig. 4. Total weight, weight of dry matter and dry-matter percentage, of the digesta in the reticulorumen at intervals after feeding at $6 \mathrm{a} . \mathrm{m}$. and $3 \mathrm{p} . \mathrm{m}$. Values are shown for cow D $(9 \mathrm{lb}$. hay, $4 \mathrm{lb}$. concentrates at each meal) after the morning, $\boldsymbol{O}$, and afternoon, $\boldsymbol{D}$, meals; and for cow W ( $9 \mathrm{lb}$. hay) after the morning, $\ominus$, and afternoon, $\Theta$, meals.

quantities in the reticulo-rumen of substances for which concentration curves are known. In order to make such predictions more accurate it is necessary to know whether the rate of decline during periods between meals was linear or curvilinear, and evidence on this point is available.

An experiment was conducted with cows D and W receiving $9 \mathrm{lb}$. hay with $4 \mathrm{lb}$. 
concentrates and $9 \mathrm{lb}$. hay, respectively, in each of two daily meals at $6 \mathrm{a} . \mathrm{m}$. and $3 \mathrm{p} . \mathrm{m}$. The reticulo-rumen was emptied, by the procedure described above, at intervals after each feed. On any one day it was emptied only once and the interval between emptyings was never less than $18 \mathrm{~h}$; each emptying time was duplicated. The time of emptying on any one day was chosen at random. The results of this experiment are presented in Fig. 4 and show that the declines both in total contents and contents of dry matter were linear and at the same rate after the morning and evening feeds. At the beginning of the morning feed the reticulo-rumen contained considerably less dry matter, but about the same weight of total contents, as before the evening feed. In consequence, therefore, the morning feed did not fill the reticulo-rumen as much as the evening feed.

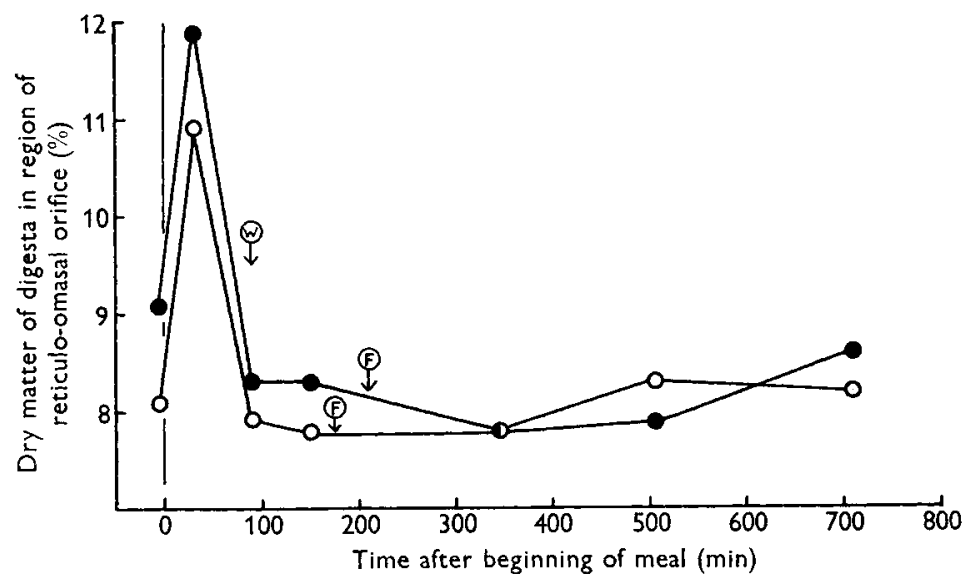

Fig. 5. Mean values for the dry-matter percentage of digesta from the region of the reticulo-omasal orifice immediately before, and at intervals after, feeding in steers $\mathrm{A}, \mathbf{O}$, and $\mathrm{D}, \mathrm{O}$, receiving $5 \mathrm{lb}$. concentrates, Io $\mathrm{lb}$. hay and $47 \mathrm{lb}$. water daily in one meal. Values are means for 4 days. The end of eating, $F$, varied slightly in the two steers. On two occasions the water, $W$, was given before the third sample was taken and on two occasions after the sample. The mean time required for drinking was $4 \mathrm{~min}$ in steer $\mathrm{A}$ and $\mathrm{II} \mathrm{min}$ in steer $\mathrm{D}$.

The experiment suggested that the reticulo-rumen emptied at the same rate, night and day, irrespective of the amount of digesta present and in spite of the tendency of the cows to lie during the night and stand during the day. Further proof that posture does not affect the rate of emptying was obtained in an experiment in which the two steers were kept standing for alternate periods of $\mathrm{I} 2 \mathrm{~h}$ (Balch, Reid \& Stroud, 1957).

From Fig. 4 it might be concluded that the digesta passing to the omasum progressively decreased in dry-matter content as the time after feeding increased. This is unlikely, however, because of the considerable formation of layers in the rumen and the tendency for the digesta in the reticulum and anterior rumen to be always low in dry-matter content. In the experiment with steers receiving only one meal daily it was found that the digesta lying in the region of the reticulo-omasal orifice, which must be similar to those passing through the orifice, showed very little change in dry-matter content throughout the $24 \mathrm{~h}$ except for a temporary rise after eating had begun and before the animal drank (Fig. 5). 
Co-ordination of water intake, saliva production, rate of jaw movement and rate of contraction of the reticulum during meals of hay

These various measurements were made simultaneously in two cows (D and $\mathrm{W}$ ) offered hay ad lib. and the results are shown in Fig. 6. It is noticeable that both cows
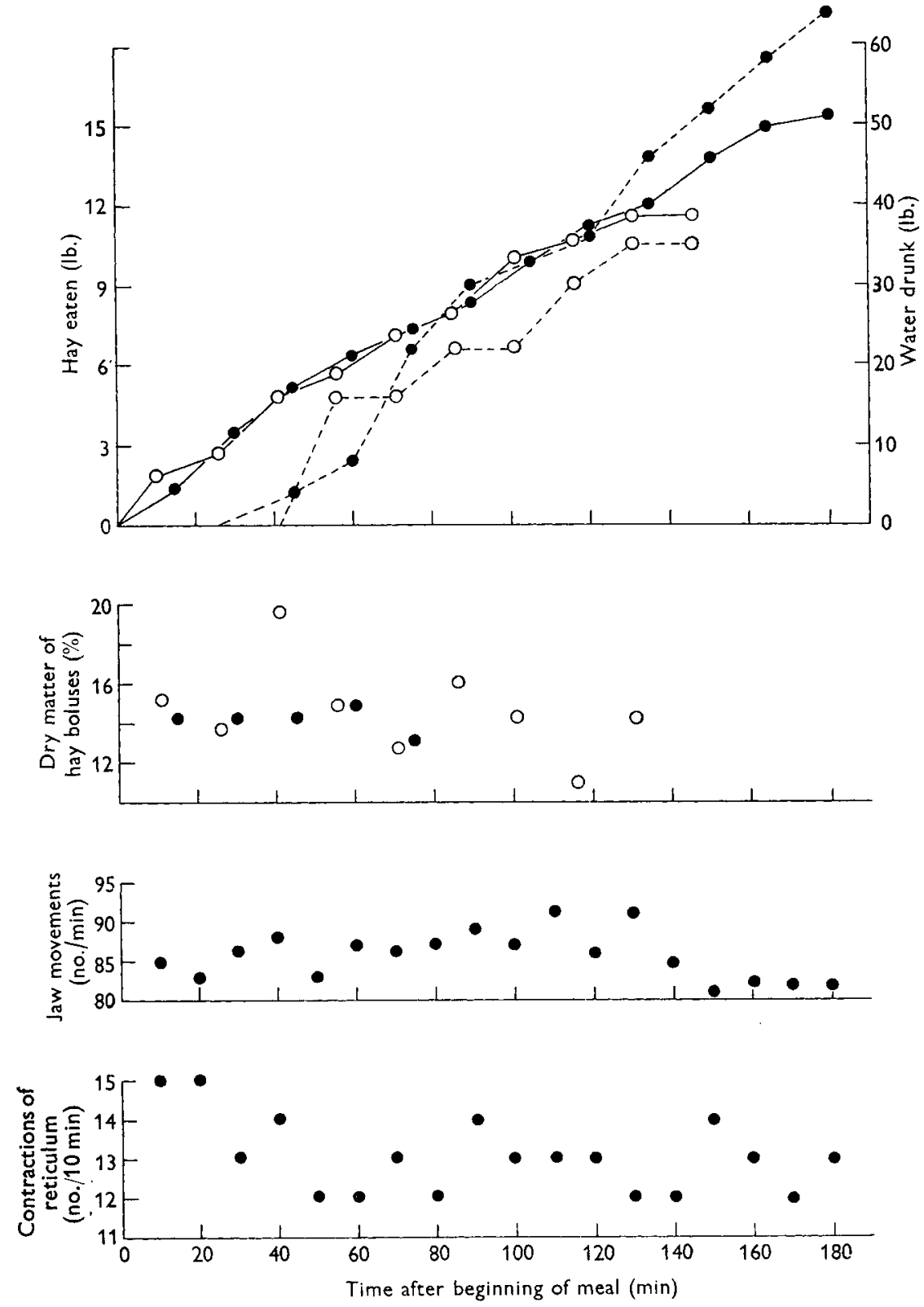

Fig. 6. Values for the rate at which hay was eaten (solid line) and water voluntarily drunk (broken line) and for the dry-matter content of hay boluses at intervals during a meal of hay $a d$ lib. in cows D, 0 ; and $W, \bullet$. Values for the rate of movement of the jaw and the rate of contraction of the reticulum in cow $\mathrm{W}$ are also shown. 
ate at a steady rate of about $5 \mathrm{lb}$./ h throughout the meal, showing only a very slight tendency to eat more slowly during about the last $20 \mathrm{~min}$. As is usual, the intake of water began some time after the commencement of eating, but then continued in frequent drinks at a fairly constant rate so long as eating continued. Cows frequently take several drinks after the end of a meal, but it is not known whether it was so in

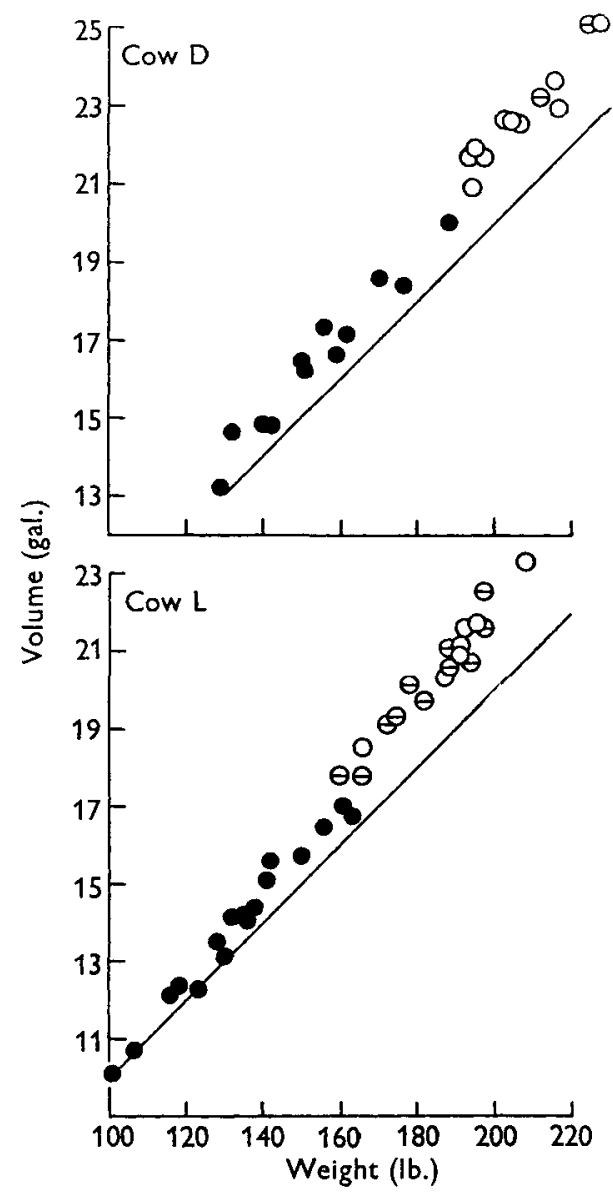

80 
during the course of the meal and only a slight tendency for the latter to decline in the initial stages of the meal.

The reticulo-rumen of each cow was emptied before and after the meal; the total amounts returned before the meal were $I_{32}$ and $1_{5} \circ \mathrm{lb}$. and the amounts found at the end were 158 and $199 \mathrm{lb}$. in cows $\mathrm{D}$ and $\mathrm{W}$, respectively. Corresponding amounts of dry matter were $12 \cdot 3$ and $12 \cdot 4 \mathrm{lb}$. before and $17 \cdot 2$ and $19 \cdot 5 \mathrm{lb}$. after eating.

\section{Relationship between the weight and volume of digesta in the reticulo-rumen}

Values for the weight and volume in gallons ( 1 gal. = 4.5 1.) of digesta in the reticulorumen of two cows receiving a variety of rations given once a day are given in Fig. 7 . They show a tendency for the specific gravity of the digesta to be rather low immediately after feeding, whereas before feeding it approached unity, especially when the rumen was rather empty. Cow $\mathrm{D}$ refused food only on two occasions, on both of which the reticulo-rumen was relatively full. Cow $\mathrm{L}$ refused food more often than not irrespective of the amount of digesta present; the refusals at the lower weights occurred with diets of $(a)$ hay, concentrates and fodder beet, and $(b)$ grass. Cow D regularly ate I6-I $8 \mathrm{lb}$. hay daily, which filled the rumen with $187-207 \mathrm{lb}$. digesta, yet only once failed to eat all the hay offered and once refused fodder beet.

\section{DISCUSSION}

\section{The act of eating}

When the cows began eating the most important immediate physiological activities were the rapid and continuous jaw movements, the large flow of saliva and the accelerated rate of reticulo-rumen movement. These were all influenced by the type of food; thus the jaw movements were of a somewhat different pattern with hay than with concentrates; the amount of saliva added per lb. hay was very much greater than per lb. concentrates, although the rate of secretion of saliva was evidently somewhat higher than with hay. The rate of contraction of the reticulum was relatively constant throughout meals of hay, but tended to decline during mixed meals containing concentrates and fodder beet in addition to hay. Drinking tended to take place mainly towards and immediately after the end of eating. Blaxter (1943) found that during eating the heart rate is accelerated, as would be expected in view of the increased muscular activity.

\section{Passage of digesta from the reticulo-rumen during eating}

It has been suggested that the passage of digesta from the reticulo-rumen to the omasum is a continuous process, brought about by the co-ordinated cycle of pressure changes in the reticulo-rumen, reticulo-omasal orifice and omasum, and that once in each cycle of contraction a small portion of digesta passes through the orifice to the omasum (Balch et al. 1950). This theory differs in some of its details from that advanced by Wester (1926) and Schalk \& Amadon (1928). From our observations on pressure changes it seemed probable that an accelerated passage of digesta occurred during eating, which was confirmed by studies on the contents of the reticulo-rumen. These showed that the rate of loss of dry matter during eating was two or three times as great 
as between meals. In these experiments it was possible to measure during eating the total losses of both dry matter and liquid from the reticulo-rumen by passage to the omasum and by absorption; the rate of disappearance from these causes has been called the rate of loss. In the absence of estimates of saliva production during resting and rumination the comparable rate of loss of dry matter, but not that of total contents, was measured between meals. It appears, however, from the observed decline in total contents between meals that their rate of loss was also much increased during eating. These studies were simplified by training the cows to one meal daily; it is probable that accelerated rates of emptying are found also with more frequent meals.

Although at any one time the rate of passage through the reticulo-omasal orifice will be controlled by such factors as the relative pressures of digesta in the reticulum and omasum in addition to the number of times the orifice opens and closes, the number of contractions of the orifice seems likely to be of considerable importance in effecting the accelerated passage during eating. The temporary rise, during eating, in the drymatter content of digesta lying near the orifice (see p. 339) may also have increased the rate of passage by raising the amount of dry matter passing to the omasum during each cycle of pressure change. Where the rate of contraction of the reticulum changed during eating, i.e. with concentrates and with fodder beet, the highest rates were early in the meal. In contrast, the greatest basal pressure between contractions was found towards the end. This pressure must continue after the meal has ended, but evidently did not influence the rate at which the reticulo-rumen emptied after feeding, because it appeared to be a linear and not a curvilinear function of the time after feeding. There is, therefore, reason for supposing that the rate of passage of food to the omasum was most rapid near the beginning of each meal. If the food boluses were being carried into the dorsal sac before disintegration (Schalk \& Amadon, 1928) it is likely that residues from earlier meals would be involved in this passage to a greater extent than the incoming food-a logical arrangement allowing food to undergo digestion for the maximum time. The obvious incompleteness of this tendency would ensure rapid and ample inoculation of the food with rumen micro-organisms. Of the incoming food it seems likely that concentrates, by reason of their smaller particle size and greater ability to absorb water, would be lost from the reticulo-rumen during eating more rapidly than hay, an observation made by Schalk \& Amadon (1928). Studies on the rate of passage of these foods (Balch, 1950) have shown that this trend does exist, undigested residues of concentrates being excreted more rapidly than those of hay.

Burroughs, Gerlaugh, Silver \& Schalk (1946) made observations on two small steers with rumen fistulas in a valuable series of experiments on the effects of level of feeding and methods of preparing maize on the amounts of digesta in the reticulo-rumen, which was emptied every $4 \mathrm{~h}$. Especially at the higher planes of feeding the rate of loss of dry matter was greatest during the period which included eating. From the results presented it is not possible to determine whether the accelerated rate of emptying was continued throughout this period of $4 \mathrm{~h}$ or was confined to the half-hour during which eating took place. It seems possible that these steers behaved similarly to my animals. 


\section{Quantities of water and saliva entering the reticulo-rumen during eating}

These investigations have disclosed the astonishing quantities of water entering the reticulo-rumen during eating. Thus the reticulo-rumen of a milking cow consuming Io $\mathrm{lb}$. hay and Io $\mathrm{lb}$. concentrates per meal might contain $\mathrm{I} 30 \mathrm{lb}$. water at the beginning of the meal. The food would then add about $3 \mathrm{lb}$. water, the cow would probably add about $50 \mathrm{lb}$. saliva with the hay, $12 \mathrm{lb}$. with the concentrates, and drink $50 \mathrm{lb}$. water, a total addition of I $_{5} \mathrm{lb}$. water. In spite of this addition the reticulo-rumen would probably not contain more than $190 \mathrm{lb}$. water at the end of the meal.

Bailey (1957, unpublished) working in this Institute has been successful in obtaining estimates of the amounts of saliva produced during resting by the technique described on p. 330 for catching food boluses. Such techniques promise to permit revision of the frequently quoted value of 561 . (Colin, 1871 ) as the mean daily saliva production of a cow. Colin showed, by means of salivary fistulas, that the flow of parotid saliva continued after the end of eating and was especially marked during eating. He was aware of the different amounts of saliva added to various foods and considered $5^{6} 1$. a minimum estimate. It is clearly so, because it can be calculated from values obtained in the present experiment that with many of the diets which might be given to a milking cow more than roo lb. $(45 \mathrm{l}$.) saliva would be produced merely during eating.

\section{Factors controlling the end of eating}

From the results of my experiments the responsibility for control of appetite in cows cannot be given to any single factor or mechanism. The number of observations during ad lib. feeding was limited. Though it appeared possible that with hay a cow might eat until her reticulo-rumen contained a given weight or volume of digesta, it was clear that this was not the limit to the appetite of cow $\mathrm{L}$, receiving mixed diets of hay, concentrates and fodder beet or of grass. Since various experiments suggested that the critical factor in appetite, even for hay, was unlikely to be either fatigue of the jaw muscles, fatigue of the reticulum musculature or cessation of salivary secretion, it seems possible that with rations containing readily digestible foods a factor other than the degree of 'fill' may be involved. Further aspects of this question of appetite are to be considered in a subsequent publication.

\section{SUMMARY}

I. The production of saliva, the movements of the jaw, the motility of the reticulum and the changes in the amount of digesta in the reticulo-rumen were studied while five cows and two steers with rumen fistulas were receiving a variety of diets.

2. For every ro $\mathrm{lb}$. hay consumed $43^{-}-57 \mathrm{lb}$. saliva were added during eating, but with every $10 \mathrm{lb}$. concentrates only $12-15 \mathrm{lb}$. saliva were added. With other foods the mean amounts of saliva added per $10 \mathrm{lb}$. dry matter were: fodder beet $30 \mathrm{lb}$. and grass $53 \mathrm{lb}$. With concentrates the rate of secretion of saliva was faster than with hay, but the rapidity of ingestion was raised so that the dry-matter content of concentrate boluses was high. The dry-matter content of hay boluses did not fall during eating. With many diets the production of saliva during eating must exceed roo lb. daily. 


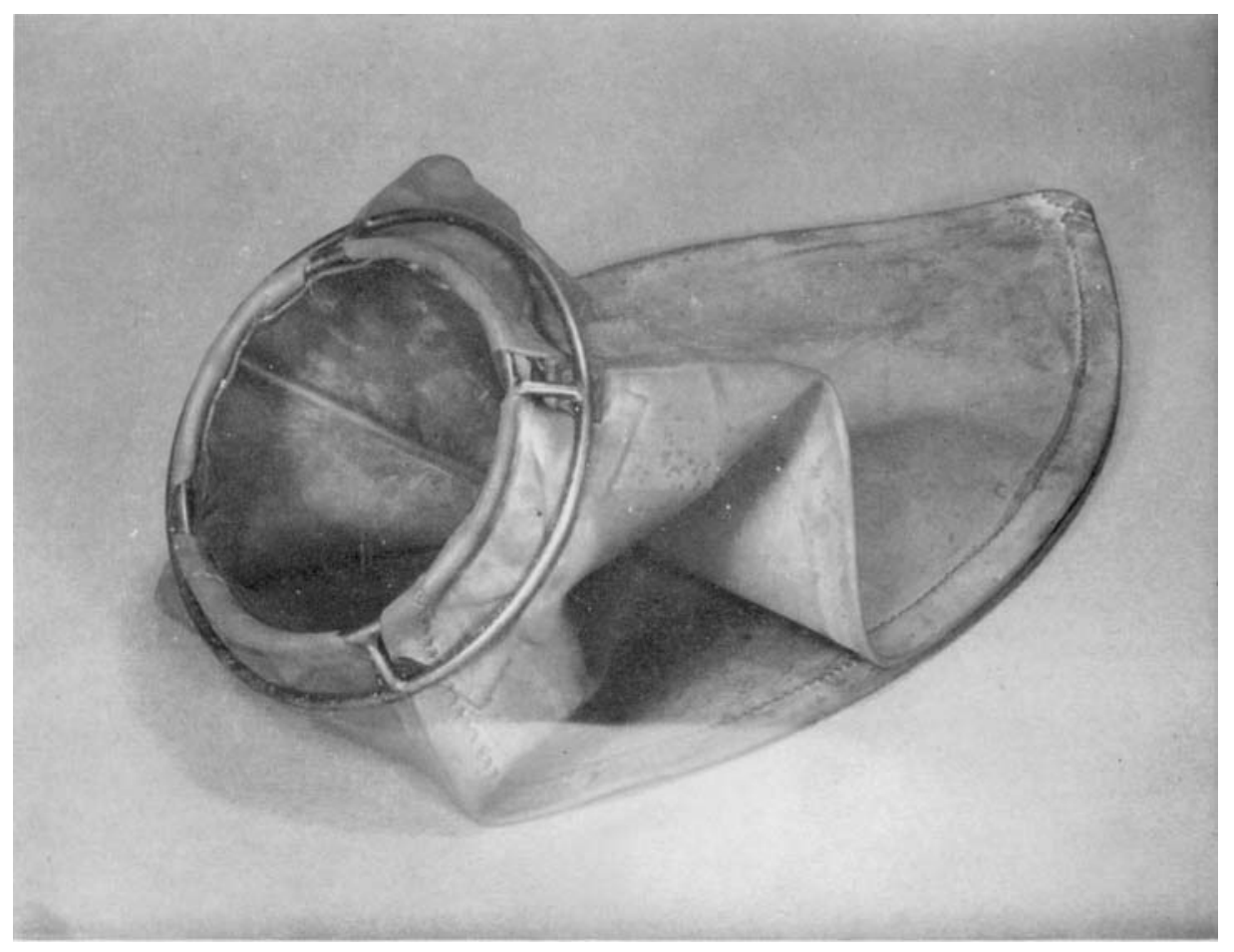

British Yournal of Nutrition, Vol. I2, No. 3 
3. There was no evidence that the rate of movement of the jaw declined even with very large meals of hay. When hay alone was eaten the rate of contraction of the reticulum was relatively constant throughout the meal, but when the ration contained concentrates, or concentrates and fodder beet, in addition to hay the rate of contraction was high initially, but tended to decline during the meal.

4. In the period between meals the mean loss of dry matter from the reticulorumen (by absorption and passage to the omasum) was $0.6-0.7 \mathrm{lb} / 100 \mathrm{~min}$ : during eating the loss rose to $\mathrm{I} \cdot 4^{-2} \cdot \mathrm{I} \mathrm{lb}$./ $100 \mathrm{~min}$.

5. The results were examined for evidence of factors responsible for cessation of eating in cows receiving rations ad lib. There was no indication, even when hay was consumed for $3 \mathrm{~h}$, of fatigue of the jaw muscles, fatigue of the reticulo-ruminal musculature, or of cessation of salivary secretion being of importance in this respect. The findings do not disprove the theory that roughages may often be consumed until a certain degree of 'fill' of the reticulo-rumen is reached, but with diets containing concentrates and fodder beet the intake was probably limited by factors other than 'fill'.

I wish to thank Mr V. W. Johnson, Mrs J. Roy, Mr D. G. Kemp and Mr D. W. Weaver for their careful help with these experiments.

\section{REFERENCES}

Balch, C. C. (1950). Brit. $\mathcal{F . ~ N u t r . ~ 4 , ~ 3 6 r . ~}$

Balch, C. C. (1952). Brit. F. Nutr. 6, 366.

Balch, C. C. \& Johnson, V. W. (1948). Vet. Rec. 6o, 446.

Balch, C. C., Kelly, A. \& Heim, G. (1950). Brit. F. Nutr. 5, 207.

Balch, C. C. \& Line, C. (1957). F. Dairy Res. 24, 1 1.

Balch, C. C., Reid, J. T. \& Stroud, J. W. (1957). Brit. F. Nutr. II, 184.

Blaxter, K. L. (1943). Vet. F.99, 2.

Burroughs, W., Gerlaugh, P., Silver, E. A. \& Schalk, A. F. (1946). F. Anim. Sci. 5, 338.

Colin, G. C. (187r). Traité de Physiologie Comparée des Animaux, 3 rd ed. Paris.

Fuller, J. M. (1928). Tech. Bull. N.H. agric. Exp. Sta. no. 35.

Schalk, A. F. \& Amadon, R. S. (1928). Bull. N. Dak. agric. Exp. Sta. no. 2 16.

Wester, J. (1926). Die Physiologie und Pathologie der Vormagen beim Rinde. Berlin: R. Schoets. 